Bull. Fac. Agric, Cairo Univ., 71:61-71 (2020).

\title{
COMPARISON BETWEEN PEDIGREE SELECTION AND INDEPENDENT CULLING LEVELS TECHNIQUS FOR IMPROVING SEED YIELD AND ITS COMPONENTS IN SESAME
}

(Received: 27. 4. 2020)

\author{
By \\ A. Abd-Elsaber and N. E. G. Mekhaile* \\ Oil Crops Research Department, Field Crops Research Institute, and * Central Laboratory for Design \\ $\&$ Statistical Analysis Research, Agricultural Research Center, Giza, Egypt.
}

\begin{abstract}
The current experiments were carried out at El-Mattana Agricultural Research Station, Luxor Governorate, Egypt, during the three summer seasons from 2016 to 2018, to compare the relative efficiency of two selection procedures, namely pedigree selection and independent culling level (ICL), for improving seed yield and its components in sesame. The genetic materials were the $\mathrm{F}_{3}, \mathrm{~F}_{4}$ and $\mathrm{F}_{5}$ generations. This study was carried out on 182 of $\mathrm{F}_{3}$ families derived from a single cross between Introduction $688 \mathrm{X}$ hybrid 102 family 2, and added $\mathrm{F}_{3}$ bulked random sample. Variations among the $\mathrm{F}_{3}$ families were highly significant for all the studied traits. The results indicated that pedigree selection decreased the genetic variability measured as genotypic coefficient of variability (GCV) of seed yield/plant and other studied traits. The GCV of seed yield/plant decreased from $28.22 \%$ in the base population to $7.79 \%$ after two cycles of selection, from 32.89 to $13.37 \%$ for capsules No./plant, from 11.11 to $7.63 \%$ for fruiting zone length, and from 13.24 to $9.20 \%$ for 1000 -seed weight. Heritability in the broad sense after two cycles of selection was high for seed yield/plant (85.69\%), capsules No./plant (96.55\%), fruiting zone length $(89.78 \%)$ and 1000-seed weight $(76.40 \%)$. The realized heritability for pedigree selection increased, indicating that increasing seed yield was accompanied with increases in related traits, and the realized heritability increased after the two cycles of ICL technique by $33.9 \%$ from the bulk sample for grain yield/plant. Heritability in the broad sense after two cycles of (ICL) was high for all the studied traits.
\end{abstract}

Key words: Sesamum indicum, Selection methods, Segregating generations, Heritability.

\section{INTRODUCTION}

Sesame (Sesamum indicum L., Pedaliaceae), a self-pollinated crop, is an ancient cultivated oil crop (Ashri, 2007), better known as "queen of oil seed crops" by virtue of its high oil quality.

Sesame growing areas in Egypt are decreasing due to low seed yield and prices compared to the other competitive summer crops in the crop rotation, and its susceptibility to root-rot diseases. Plant breeders are continuously searching for more effective and efficient methods to improve seed yield. Although several selection methods were used to improve several traits, pedigree selection method has become the most popular of plant breeding procedures. Plant breeders prefer it because it is versatile, relatively rapid and makes possible the conducting of genetic studies along with the plant breeding work. AboElwafa and Ahmed (2005) found that the observed gain in seed yield of two populations was better when selection was practiced for seed yield per se (25.24 and $15.22 \%$ of the better parent) than selection for weight of capsules/plant after two cycles of pedigree selection. In addition, the positive relationship between seed yield and the other traits such as capsules number, fruiting zone length and 1000-seed weight proved rewarding in breeding for high yield in sesame (El-Shakhess et al., 2002). ElShimy (2005) found that the observed gain in seed yield/plant reached 49.12 and 45.78 $\%$ of the better parent when selection was practiced for seed yield in two populations after two cycles. However, the correlated gains were 40.29 and $3.87 \%$, and 29.90 and $6.19 \%$ when selection was exerted for 
fruiting zone length and capsules No./plant, respectively. In another two populations, El-Shimy et al. (2005) found great depletion of genetic coefficient of variability from $\mathrm{F}_{3}(22.5$ and $22.82 \%)$ to $\mathrm{F}_{6}$ generation (3.66 and $4.18 \%$ ) and recorded observed gain of 28.64 and $31.53 \%$ of the bulk sample of the two populations after three cycles of pedigree selection for seed yield. High heritability, phenotypic and genotypic coefficients of variability for plant height, capsules No./plant, days to 50 $\%$ flowering and seed yield/plant were reported by Parameshwarappa et al. (2009), Chowdhury et al. (2010), and Akbar et al. (2011). And, high expected gain were reported by Sumathi and Muralidharam (2010), Ismaila and Usman (2012) and Menzir (2012). On the contrary, Sivaprased and Yadavalli (2012) found low genotypic variability, heritability and expected gain in seed yield/plant in the $F_{2}$ and $F_{3}$ generations. Many investigators reported high genotypic and phenotypic coefficients of variability and genetic advance in seed yield and its components in sesame (Gidey et al., 2013; and Ismail et al., 2013).

The efficiency of a breeding program is largely dependent on the efficiency of selection criteria and the selection method used. The present study was carried out to compare the efficiency of two selection methods, namely pedigree method and independent culling levels method in one population of sesame.

\section{MATERIALS AND METHODS}

The present study was carried out at El Mattana Agricultural Research Station, Luxor Governorate, Egypt, during the three successive summer seasons 2016, 2017 and 2018. The breeding material used in this study was $180 \quad F_{3}$ families traced back to random $F_{2}$ plants from the cross: Introduction $688 \mathrm{X}$ hybrid 102 family2 (Table 1). sample (a mixture of equal No. of seeds from each plant to represent the generation mean) were sown on April $15^{\text {th }}$ in a randomized complete block design with three replications according to Steel et al. (1997). Each plot was a single row of $4 \mathrm{~m}$ long, $55 \mathrm{~cm}$ apart, and $10 \mathrm{~cm}$ between hills within a row. Each parent was sown in two rows, in addition to $F_{3}$ family was sown in one row and the bulked population was sown in two rows each replicate. The recommended cultural practices were adopted throughout the growing season. The following traits were measured on ten guarded random plants in each plot:

Plant height $(\mathrm{cm})$, fruiting zone length (cm), branches No./plant, capsule length (cm); capsules No./plant, seed yield/plant (g), 1000-seed weight (g) (calculated from the selected plants), seed oil percentage: determined by using petroleum either (Bp $40-60^{\circ}$ ) as solvent in Soxhalet apparatus according to the method of A.O.A.C. (1980).

Concerning the pedigree selection method, the best 30 plants of the base $F_{3}$ population based on superiority of seed yield/plant were saved to give the $F_{4}$ families. Furthermore, the best 30 plants fulfilled the following ICL method for the three traits were selected for the next cycle of the population and selection was applied for the studied traits according to the following levels (fruiting zone length $\geq 103$ $\mathrm{cm}$, capsules No./plant $\geq 82$ and seed yield/plant $\geq 22 \mathrm{~g}$ ).

In 2017 season $\left(\mathrm{F}_{4}\right.$ generation), the 30families selected for pedigree selection and independent culling levels along with the parents and $F_{4}$ bulk sample were sown on May $15^{\text {th }}$ in two separate experiments in a randomized complete block design with three replications. Each group of families (30 families) for seed yield/plant (pedigree selection) and independent culling levels were analyzed separately. The best 10 families for seed yield/plant and independent

Table (1): The details of the studied sesame genotypes in this experiment.

\begin{tabular}{|c|l|c|c|c|}
\hline No & \multicolumn{1}{|c|}{ Genotype } & \multirow{2}{*}{ Origin } & \multicolumn{2}{|c|}{ Main description } \\
\cline { 4 - 5 }$\cdot$ & & & Capsules No./ leaf axel & Branching habit \\
\hline 1 & Introduction 688 & FAO & Single & Non branched \\
\hline 2 & Hybrid 102 family 2 & Egypt & Three & Branched \\
\hline
\end{tabular}

In 2016 season, the $182 \quad F_{3}$ families with the original parents and $\mathrm{F}_{3}$ bulked random culling levels were saved to give the $F_{5}$ families. 
In 2018 season, the $10-\mathrm{F}_{5}$ families covering all selection procedures with the the parents and $\mathrm{F}_{5}$ bulk sample were sown as previous seasons. The data were scored as in the earlier experiments.

\subsection{Statistical analysis}

For each season, estimates of phenotypic $\left(\sigma_{p h}^{2}\right)$ and genotypic variance $\left(\sigma_{g}^{2}\right)$ and covariance, as well as broad sense heritability estimates were calculated from expected mean square (EMS) of the variance and covariance components of the selected families as presented in Table (2).

Table (2): The analysis of variance and mean square expectations.

\begin{tabular}{|c|c|c|c|}
\hline S.O.V & d.f & MS & $\begin{array}{c}\text { Expected mean } \\
\text { squares }\end{array}$ \\
\hline Replications & $\mathrm{r}-1$ & & \\
\hline Genotypes & $\mathrm{g}-1$ & $\mathrm{M}_{2}$ & $\sigma^{2} \mathrm{e}+\mathrm{r}^{2} \mathrm{~g}$ \\
\hline Error & $(\mathrm{r}-1)(\mathrm{g}-1)$ & $\mathrm{M}_{1}$ & $\sigma^{2} \mathrm{e}$ \\
\hline
\end{tabular}

Where: $\mathrm{r}$ and $\mathrm{g}=$ replications No. and genotypes No., respectively.

$\sigma_{e}^{2}=$ error variance. $\quad \sigma_{g}^{2}=$ genetic variance.

The phenotypic $\left(\sigma_{p h}^{2}\right)$ and genotypic $\left(\sigma_{g}^{2}\right)$ variances were estimated as given by Al-Jibouri et al. (1958):

The genotypic variance $\sigma_{g}^{2}=\left(M_{2}-M_{1}\right) / r$

The phenotypic variance $\sigma_{p h}^{2}=\sigma_{g}^{2}+\sigma_{e}^{2} / r$

The genetic covariance (cov. $\mathrm{g}_{12}$ ) and phenotypic covariance (cov. $\mathrm{p}_{12}$ ) between pairs of traits (1 and 2) were calculated according to Steel et al. (1997) as follows:

-Broad sense heritability $H=\left(\sigma_{g}^{2} / \sigma_{p h}^{2}\right) * 100$

- The phenotypic (PCV \%) and genotypic (GCV

$\%$ ) coefficients of variability were estimated according to Burton (1952).

Phenotypic coefficient variability (PCV):
$P C V \%=\left(\frac{\sigma_{p h}}{\bar{x}}\right) * 100$

Genotypic coefficient of variability:

$P C V \%=\left(\frac{\sigma_{g}}{-}\right) * 100$

Where: $\sigma_{p h}$ and $\sigma_{g}$ are the phenotypic and genotypic standard deviations of the families,

respectively, and $\bar{x}$ is the family mean for a given trait.

Realized heritability was calculated according to Falconer (1989) from the equation of response, i.e. $\mathrm{R}=\mathrm{S} \mathrm{h}^{2}$, which were discussed earlier from the point of view of predicting the response to selection, the heritability being estimated as the ratio of the $h^{2}=R / S$, where:

$$
\begin{aligned}
& \mathrm{R}=\text { is response to selection } \\
& \mathrm{S}=\text { is selection differential. }
\end{aligned}
$$

\section{RESULTS AND DISCUSSION}

\subsection{Description of the base population}

The analysis of variance (Table 3) indicated highly significant differences among $\mathrm{F}_{3}$ - families for all the studied traits, indicating the presence of variability among the genotypes. The results of (GCV) and (PCV) are presented in Table (4). The traits of the starting population had a significant effect on early generation selection and the slight difference between (GCV) and (PCV) resulted in high estimates of broad sense heritability for most studied traits.

Greater response to selection could be expected in a population having greater phenotypic and genotypic variances. These data resulted in wide ranges and high estimates of broad sense heritability (more than $64 \%$ ) for all studied traits in base population $\left(\mathrm{F}_{3}\right.$ generation).

High genotypic and phenotypic variations and heritability for yield and its components were reported by Parameshwarappa et al. (2009), Sumathi and Muralidharon (2010) Ismaila and Usman (2012) and Kumar et al. (2012).

\begin{tabular}{|c|c|c|c|c|c|c|c|c|c|}
\hline \multirow[b]{2}{*}{ S.O.V } & \multirow[b]{2}{*}{ d.f } & \multicolumn{8}{|c|}{ Mean squares } \\
\hline & & $\begin{array}{l}\text { Plant } \\
\text { height }\end{array}$ & $\begin{array}{c}\text { Fruiting } \\
\text { zone } \\
\text { length }\end{array}$ & $\begin{array}{c}\text { Capsule } \\
\text { length }\end{array}$ & $\begin{array}{l}\text { Branches } \\
\text { No./ plant }\end{array}$ & $\begin{array}{l}\text { Capsules } \\
\text { No./ plant }\end{array}$ & $\begin{array}{c}\text { Seed } \\
\text { yield } / \\
\text { plant }\end{array}$ & $\begin{array}{c}1000- \\
\text { seed } \\
\text { weight }\end{array}$ & $\begin{array}{l}\text { Oil } \\
\%\end{array}$ \\
\hline Replication & 2 & 2500.65 & 3122.51 & 0.90 & 1.59 & 16919.13 & 372.19 & 24.15 & 1.23 \\
\hline Genotypes & 181 & $1429.65 * *$ & $817.64 * *$ & $0.57 * *$ & $1.64 * *$ & $3067.09 * *$ & $202.62 * *$ & $1.09 * *$ & $139.54 * *$ \\
\hline Error & 362 & 358.94 & 274.59 & 0.20 & 0.41 & 658.65 & 72.02 & 0.32 & 34.38 \\
\hline
\end{tabular}

Table (3): Mean squares for the studied traits of the base population $\left(F_{3}\right)$.

**significant at the 0.01 level. 
Table (4): Means, phenotypic (PCV \%), genotypic (GCV \%) coefficients of variability and heritability in broadsense for the studied traits in the $F_{3}$ families.

\begin{tabular}{|c|c|c|c|c|c|c|c|c|}
\hline Item & $\begin{array}{c}\text { Plant } \\
\text { height } \\
\text { (cm) }\end{array}$ & $\begin{array}{l}\text { Fruiting } \\
\text { zone } \\
\text { length } \\
(\mathrm{cm}) \\
\end{array}$ & $\begin{array}{c}\text { Capsule } \\
\text { length } \\
(\mathrm{cm}) \\
\end{array}$ & $\begin{array}{l}\text { Branches } \\
\text { No./plant }\end{array}$ & $\begin{array}{l}\text { Capsules } \\
\text { No./plant } \\
\end{array}$ & $\begin{array}{c}\text { Seed } \\
\text { yield/plant } \\
(\mathrm{g}) \\
\end{array}$ & $\begin{array}{c}1000- \\
\text { seed } \\
\text { weight } \\
(\mathrm{g}) \\
\end{array}$ & $\begin{array}{l}\text { Oil } \\
\%\end{array}$ \\
\hline Mean & 186.27 & 121.12 & 3.49 & 3.48 & 86.14 & 23.38 & 3.83 & $\mathbf{5 0 . 5 7}$ \\
\hline Maximum & 253.33 & 157.67 & 5.40 & 7.67 & 191.67 & 46.10 & 6.67 & 66.58 \\
\hline Minimum & 123.33 & 68.67 & 2.33 & 1.00 & 50.40 & 10.07 & 2.73 & 32.67 \\
\hline $\mathbf{P}_{1}$ & 189.33 & 116.67 & 3.63 & 3.67 & 79.00 & 19.33 & 3.12 & 57.69 \\
\hline $\mathbf{P}_{2}$ & 245.00 & 153.33 & 4.00 & 4.00 & 95.33 & 22.40 & 2.90 & 55.00 \\
\hline Bulk & 179.70 & 121.12 & 3.49 & 3.48 & 86.14 & 23.38 & 3.83 & 48.72 \\
\hline CV\% & 10.17 & 13.68 & 12.71 & 18.49 & 29.79 & 36.30 & 14.66 & 11.59 \\
\hline GCV \% & 10.14 & 11.11 & 10.03 & 18.35 & 32.89 & 28.22 & 13.24 & 11.71 \\
\hline PCV \% & 11.72 & 13.63 & 12.43 & 21.23 & 37.12 & 35.15 & 15.71 & 13.49 \\
\hline Heritability \% & 74.89 & 66.42 & 65.14 & 74.72 & 78.53 & 64.46 & 70.97 & 75.36 \\
\hline
\end{tabular}

\subsection{Pedigree selection}

The pedigree selection was practiced on the population of sesame for seed yield/plant.

\subsubsection{Variances and means}

The analysis of variance for the selected families for seed yield/plant and other traits in cycle $1 \quad\left(\mathrm{~F}_{4}\right.$ generation $)$ and cycle $2 \quad\left(\mathrm{~F}_{5}\right.$ generation) is presented in Table (5). The results indicated highly significant differences among genotypes. This result reflected the genetic make-up of those selected families in population; consequently offer good chance for selection.

The average seed yield/plant of the selected families in Table (6) increased from $34.74 \mathrm{~g}$ in $\mathrm{F}_{4}$ generation (cycle 1) to $41.49 \mathrm{~g}$ in $\mathrm{F}_{5}$ generation (cycle 2). The average seed yield/plant for the bulk population was 20.00 and $27.00 \mathrm{~g}$ in the $\mathrm{F}_{4}$ and the $\mathrm{F}_{5}$ generations, respectively.

The results indicated that pedigree selection decreased the genetic variability measured as genotypic coefficient of variability of the selection criterion and other traits after two cycles of selection. This may due to the low No. of selected families (ten families out of 30 families) and increasing the percentage of the homozygosity than in the $F_{5}$ generation. However, the (GCV) of seed yield/plant decreased from $28.22 \%$ in the base population (Table 6) to $7.79 \%$ after two cycles of selection from $32.89 \%$ to $13.37 \%$ for capsules No./plant, from $11.11 \%$ to $7.63 \%$ for fruiting zone length, and from 13.63 to $7.96 \%$ for capsule length. The phenotypic coefficients of variation (PCV) values were in line with those recorded for (GCV) in population. Falconer (1989) stated that selection reduces genotypic variance of the following generation. The results indicated that pedigree selection decreased the genetic variability measured as genotypic coefficient of variability for seed yield/plant the studied traits

Table (5): Analysis of variance after the first and second cycles of pedigree selection for seed yield/plant.

\begin{tabular}{|c|c|c|c|c|c|c|c|c|c|c|}
\hline \multirow[b]{2}{*}{$\begin{array}{c}\text { Cycle } \\
\text { No. }\end{array}$} & \multirow[b]{2}{*}{ S.O.V } & \multirow[b]{2}{*}{ d.f } & \multicolumn{8}{|c|}{ Mean squares } \\
\hline & & & $\begin{array}{c}\text { Plant } \\
\text { height }\end{array}$ & $\begin{array}{c}\text { Fruiting } \\
\text { zone } \\
\text { length } \\
\end{array}$ & $\begin{array}{c}\text { Capsule } \\
\text { length }\end{array}$ & $\begin{array}{c}\text { Branches } \\
\text { No. / } \\
\text { plant } \\
\end{array}$ & $\begin{array}{c}\text { Capsules } \\
\text { No. / } \\
\text { plant } \\
\end{array}$ & $\begin{array}{l}\text { Seed } \\
\text { yield/ } \\
\text { plant }\end{array}$ & $\begin{array}{c}\text { 1000- } \\
\text { seed } \\
\text { weight }\end{array}$ & $\begin{array}{l}\text { Oil } \\
\%\end{array}$ \\
\hline \multirow{3}{*}{$\begin{array}{l}\mathrm{C}_{1} \\
(\mathrm{~F} 4)\end{array}$} & Replication & 2 & 72.12 & 506.80 & 5.26 & 0.67 & 6157.33 & 10.52 & 1.08 & 13.16 \\
\hline & Genotypes & 29 & $1037.34 * *$ & $466.65^{* *}$ & $0.74 * *$ & $1.39 * *$ & $2220.57 * *$ & $2135.02 * *$ & $0.72 * *$ & $123.95^{* *}$ \\
\hline & Error & 58 & 141.97 & 52.48 & 0.19 & 0.42 & 225.24 & 1023.64 & 0.12 & 16.77 \\
\hline \multirow{3}{*}{$\begin{array}{l}\text { C2 } \\
\text { (F5) }\end{array}$} & Replication & 2 & 441.23 & 295.61 & 1.19 & 0.13 & 1997.65 & 35.47 & 2.47 & 8.93 \\
\hline & Genotypes & 9 & $846.19 * *$ & $334.11 * *$ & $0.46^{* *}$ & $1.18^{* * *}$ & $1018.23 * *$ & $85.60 * *$ & $0.60 * *$ & $83.60 * *$ \\
\hline & Error & 18 & 86.40 & 49.54 & 0.09 & 0.27 & 94.20 & 17.24 & 0.14 & 8.57 \\
\hline
\end{tabular}

\footnotetext{
**significant at 0.01 level.
} 
of the two cycles of selection which is in agreement with Abo-Elwafa and Ahmed (2005), El-Shimy (2005), Ismail et al.(2013) and Mahdy et al. (2015).

\subsubsection{Heritability and realized heritability estimates}

Theoretically, heritability estimate of family means increases with the increase in homozygosity. The results in (Table 6) indicated that heritability estimates increased from the $F_{4}$ (cycle 1) to the $F_{5}$ generation (cycle 2) for all studied traits. Estimates of heritability in broad sense after two cycles of selection were high for seed yield/plant (85.69\%), 1000-seedweight $(95.98 \%)$ capsules No./plant $(96.55 \%)$ and fruiting zone length $(89.78 \%)$.

The realized heritability estimated from the realized gain in both cycles of single trait selection in the studied population decreased from $\mathrm{C}_{1}$ to $\mathrm{C}_{2}$ for seed yield/plant and all studied traits, revealing the less genetic variation in $\mathrm{C}_{2}$ comparing to $\mathrm{C}_{1}$ (Table 6 ).

\subsubsection{The expected genetic gain from selection}

Results in Table (7) show the expected genetic gain $(\Delta G)$ based on the proportion of the selected families in population after carrying out two cycles of pedigree selection. High and moderate estimates of broad sense heritability were coupled high estimates of expected genetic gain from selection of $16.5 \%$ and $33 \%$ superior plants of pedigree selection for seed yield/plant in the $F_{4}$ and $F_{5}$ generations, respectively (Table 7). With respect to the expected genetic gain from selection calculated from bulk means and better parents, the data clearly demonstrate high percentage of the expected genetic gain in relation to better parents in most studied traits.

Table (6): Means, range, phenotypic (PCV \%), genotypic (GCV \%) coefficients of variability, heritability in broad-sense (H.B.S) and realized heritability in the two cycles of pedigree selection for seed yield/plant.

\begin{tabular}{|c|c|c|c|c|c|c|c|c|c|c|}
\hline $\begin{array}{c}\text { Cycle } \\
\text { No. }\end{array}$ & \multicolumn{2}{|c|}{ Item } & $\begin{array}{c}\text { Plant } \\
\text { height } \\
(\mathrm{cm})\end{array}$ & $\begin{array}{l}\text { Fruiting } \\
\text { zone } \\
\text { length } \\
\text { (cm) }\end{array}$ & $\begin{array}{c}\text { Capsule } \\
\text { length } \\
\text { (cm) }\end{array}$ & $\begin{array}{c}\text { Branches } \\
\text { No./ } \\
\text { plant }\end{array}$ & $\begin{array}{c}\text { Capsules } \\
\text { No./ } \\
\text { plant }\end{array}$ & $\begin{array}{c}\text { Seed } \\
\text { yield/ } \\
\text { plant } \\
(\mathrm{g})\end{array}$ & $\begin{array}{c}\text { 1000- } \\
\text { seed } \\
\text { weight } \\
(\mathrm{g}) \\
\end{array}$ & $\begin{array}{l}\text { Oil } \\
\%\end{array}$ \\
\hline \multirow{11}{*}{$\begin{array}{c}\mathbf{C}_{1} \\
\left(\mathbf{F}_{4}\right)\end{array}$} & \multirow{2}{*}{ Range } & Min. & 185.00 & 112.00 & 2.73 & 2.47 & 82.00 & 28.00 & 2.91 & 37.60 \\
\hline & & Max. & 253.33 & 169.00 & 5.10 & 5.30 & 182.67 & 47.03 & 4.90 & 61.00 \\
\hline & \multicolumn{2}{|c|}{$\begin{array}{l}F_{4} \text { selected } \\
\text { families }\end{array}$} & 212.39 & 132.57 & 4.20 & 3.59 & 120.95 & 34.74 & 4.02 & 52.94 \\
\hline & \multicolumn{2}{|l|}{$\mathbf{P}_{1}$} & 189.33 & 116.67 & 3.63 & 3.33 & 80.67 & 17.67 & 3.12 & 57.69 \\
\hline & \multicolumn{2}{|l|}{$\mathbf{P}_{2}$} & 232.33 & 147.33 & 4.00 & 3.67 & 95.33 & 20.90 & 2.90 & 55.50 \\
\hline & \multicolumn{2}{|l|}{ Bulk } & 203.33 & 138.33 & 4.00 & 4.00 & 106.00 & 20.00 & 3.80 & 51.93 \\
\hline & \multicolumn{2}{|l|}{ CV\% } & 5.61 & 5.46 & 10.36 & 17.96 & 12.41 & 12.09 & 9.94 & 7.74 \\
\hline & \multicolumn{2}{|c|}{ GCV \% } & 8.13 & 8.86 & 10.21 & 15.89 & 21.32 & 12.43 & 11.11 & 11.29 \\
\hline & \multicolumn{2}{|l|}{ PCV \% } & 8.76 & 9.41 & 11.83 & 18.97 & 22.49 & 14.26 & 12.20 & 12.14 \\
\hline & \multicolumn{2}{|c|}{ H.B.S \% } & 86.31 & 88.75 & 74.46 & 70.13 & 89.86 & 76.03 & 82.90 & 86.47 \\
\hline & \multicolumn{2}{|c|}{$\begin{array}{l}\text { Realized } \\
\text { heritability }\end{array}$} & 0.63 & 0.87 & 0.79 & 0.49 & 0.96 & 0.88 & 0.70 & 0.24 \\
\hline \multirow{11}{*}{$\begin{array}{c}\mathbf{C}_{2} \\
\left(\mathbf{F}_{5}\right)\end{array}$} & \multirow{2}{*}{ Range } & Min. & 174.00 & 122.67 & 3.82 & 2.77 & 117.33 & 36.80 & 3.47 & 42.15 \\
\hline & & Max. & 233.50 & 163.67 & 5.06 & 4.64 & 172.67 & 46.50 & 4.87 & 59.26 \\
\hline & \multicolumn{2}{|c|}{$\begin{array}{l}F_{5} \text { selected } \\
\text { families }\end{array}$} & 213.07 & 136.77 & 4.42 & 3.67 & 135.35 & 41.49 & 4.26 & 53.97 \\
\hline & \multicolumn{2}{|l|}{$\mathbf{P}_{1}$} & 189.33 & 116.67 & 3.63 & 3.67 & 79.00 & 17.00 & 3.12 & 57.69 \\
\hline & \multicolumn{2}{|l|}{$\mathbf{P}_{2}$} & 220.00 & 153.33 & 4.00 & 4.00 & 95.33 & 20.47 & 2.90 & 55.00 \\
\hline & \multicolumn{2}{|l|}{ Bulk } & 203.33 & 138.33 & 4.00 & 4.00 & 106.00 & 27.00 & 3.20 & 48.50 \\
\hline & \multicolumn{2}{|l|}{ CV\% } & 4.36 & 5.13 & 6.62 & 14.20 & 7.17 & 9.98 & 8.86 & 5.43 \\
\hline & \multicolumn{2}{|c|}{ GCV \% } & 7.47 & 7.63 & 7.96 & 15.01 & 13.37 & 7.79 & 10.32 & 9.27 \\
\hline & \multicolumn{2}{|c|}{ PCV \% } & 7.88 & 8.06 & 8.83 & 17.10 & 13.61 & 8.42 & 10.53 & 9.78 \\
\hline & \multicolumn{2}{|c|}{ H.B.S \% } & 89.79 & 89.78 & 81.27 & 77.01 & 96.55 & 85.69 & 95.98 & 89.74 \\
\hline & \multicolumn{2}{|c|}{$\begin{array}{l}\text { Realized } \\
\text { heritability }\end{array}$} & 0.91 & 0.17 & 0.28 & 0.36 & 0.32 & 0.24 & 0.59 & 0.54 \\
\hline
\end{tabular}


Table (7): Expected genetic advance $(\Delta G)$ of the population and as percentage from bulk mean and better parent after $F_{4}$ (cycle 1$)$ and $F_{5}$ (cycle 2) generation of pedigree selection for seed yield/plant and independent culling levels (ICL).

\begin{tabular}{|c|c|c|c|c|c|c|c|c|c|c|}
\hline Item & Generation & $\begin{array}{c}\text { Expected } \\
\text { gain } \\
\text { estimates }\end{array}$ & $\begin{array}{l}\text { Plant } \\
\text { height } \\
(\mathrm{cm})\end{array}$ & $\begin{array}{l}\text { Fruiting } \\
\text { zone } \\
\text { length } \\
(\mathrm{cm}) \\
\end{array}$ & $\begin{array}{c}\text { Capsule } \\
\text { length } \\
(\mathrm{cm})\end{array}$ & $\begin{array}{c}\text { Branches } \\
\text { No./ } \\
\text { plant }\end{array}$ & $\begin{array}{c}\text { Capsules } \\
\text { No./ } \\
\text { plant }\end{array}$ & $\begin{array}{c}\text { Seed } \\
\text { yield/ } \\
\text { plant } \\
(\mathrm{g})\end{array}$ & $\begin{array}{c}1000- \\
\text { seed } \\
\text { weight } \\
(\mathrm{g}) \\
\end{array}$ & $\begin{array}{l}\text { Oil } \\
\%\end{array}$ \\
\hline \multirow[b]{6}{*}{$\mathrm{SY} / \mathrm{PL}$} & \multirow{3}{*}{$\begin{array}{c}\mathrm{F}_{4} \\
\text { generation }\end{array}$} & $\Delta \mathrm{G}$ & 24.08 & 16.60 & 0.56 & 0.72 & 36.67 & 5.65 & 0.60 & 8.34 \\
\hline & & $\Delta \mathrm{G} / \mathrm{bulk}$ & 11.84 & 12.00 & 13.89 & 17.93 & 34.59 & 28.25 & 15.67 & 16.05 \\
\hline & & $\Delta \mathrm{G} /$ better & 10.36 & 11.27 & 13.89 & 19.56 & 38.47 & 27.03 & 19.08 & 14.45 \\
\hline & \multirow{3}{*}{$\begin{array}{c}\mathrm{F}_{5} \\
\text { generation }\end{array}$} & $\Delta \mathrm{G}$ & 17.49 & 10.43 & 0.37 & 0.56 & 19.39 & 4.95 & 0.40 & 5.50 \\
\hline & & $\Delta \mathrm{G} / \mathrm{bulk}$ & 8.60 & 7.54 & 9.19 & 14.02 & 18.30 & 18.33 & 12.44 & 11.33 \\
\hline & & $\Delta \mathrm{G} /$ better & 7.95 & 6.80 & 9.19 & 14.02 & 20.34 & 24.18 & 12.75 & 9.53 \\
\hline \multirow[b]{6}{*}{ ICL } & \multirow{3}{*}{$\begin{array}{c}\mathrm{F}_{4} \\
\text { generation }\end{array}$} & $\Delta \mathrm{G}$ & 32.19 & 27.90 & 0.46 & 0.90 & 48.35 & 12.52 & 0.72 & 6.97 \\
\hline & & $\Delta \mathrm{G} / \mathrm{bulk}$ & 15.83 & 20.17 & 11.41 & 22.48 & 45.62 & $62 . \overline{61}$ & 18.90 & 13.42 \\
\hline & & $\Delta \mathrm{G} /$ better & 12.87 & 23.92 & 12.56 & 24.52 & 61.21 & 96.32 & 12.88 & 11.96 \\
\hline & \multirow{3}{*}{$\underset{\text { generation }}{\mathrm{F}_{5}}$} & $\Delta \mathrm{G}$ & 14.09 & 19.36 & 0.49 & 0.79 & 30.75 & 4.76 & 0.44 & 5.95 \\
\hline & & $\Delta \mathrm{G} / \mathrm{bulk}$ & 6.93 & 14.00 & 12.20 & 19.82 & 29.01 & 23.81 & 12.45 & 11.46 \\
\hline & & $\Delta \mathrm{G} /$ better & 6.41 & 12.63 & 12.20 & 19.82 & 32.26 & 23.26 & 15.31 & 10.81 \\
\hline
\end{tabular}

$\mathrm{SY} / \mathrm{PL}=$ Seed yield/plant, $\mathrm{ICL}=$ Independent culling level, $\Delta \mathrm{G}=$ Population expected genetic gain, $\Delta \mathrm{G} / \mathrm{bulk}=\mathrm{Bulk}$ mean expected genetic gain, $\Delta \mathrm{G} /$ bulk $=$ Better mean expected genetic gain .

Concerning the genetic advance as percentage of bulk mean after carrying out two cycles of pedigree selection for seed yield/plant was high for seed yield/plant $(18.33 \%)$ followed by capsules No. (18.30\%), branches No./plant (14.02\%) and 1000-seeds weight $(12.44 \%)$. It was minimum for each of fruiting zone length $(7.54 \%)$ and plant height (8.60 \%). Similarly, genetic advance as percentage of better parent was high for seed yield/plant $(24.18 \%)$ followed by capsules No. $(20.34 \%)$ after carrying out two cycles of pedigree selection (Table 7).

\subsubsection{Observed direct and correlated} responses after carrying out two cycles of pedigree selection for seed yield/plant

Results in Table (8) show the means (observed direct) of the best 10 families selected according to seed yield/plant and correlated response after carrying out two cycles of pedigree selection in the $\mathrm{F}_{5}$ generation. The correlated response was estimated as percentage from bulk mean and better parent. The pedigree selection method succeeded to isolate superior genotypes in seed yield/plant with one or more effective attributed traits.

Plant height ranged from $184.0 \mathrm{~cm}$ for family No.52 to $243.5 \mathrm{~cm}$ for No.115. Nine and eight families out of ten were significantly taller than the bulk mean and the taller parent, respectively (Table 8). Likewise, the highest length of the fruiting zone length of the selected families ranged from $122.7 \mathrm{~cm}$ for family No.52 to 163.7 $\mathrm{cm}$ for No.128 with an average of 136.8 cm. Branches No./plant of the selected families ranged from 2.8 for No.111 to 4.6 branches for No.127. All families had branches No./plant than the better parent, except only three families (No.52, No.127 and No.128).

The results revealed that there was a wide range in capsules No./plant, i.e. from 117.3 for No.122 to 155.2 for No.128 with an average of 135.4 capsules. Most of the selected families were significantly higher in capsules No./plant than both of bulk sample and the better parent. It is also clear that the family No.127 was superior from bulk sample and better parent by 62.9 and $81.1 \%$, respectively. The seed yield of the ten selected families ranged between 37.3 and $46.5 \mathrm{~g}$ with an average of $41.5 \mathrm{~g}$. All families did not differ significantly and the family No. 122 was the best family from them and recorded increase of about, 72.2 and $127.2 \%$ in seed yield than bulk mean and better parent, respectively (Table 8).

Concerning 1000-seed weight, the ten selected families ranged between 3.5 and $4.9 \mathrm{~g}$ with an average of $4.3 \mathrm{~g}$. The family No. 115 differed significantly and had heavier 1000-seeds weight than both of bulk sample and better parent, and recorded an increase of 52.1 and $56.0 \%$, respectively. For oil percentage trait, eight 
Table (8): Observed direct and correlated responses after two cycles of pedigree selection for seed yield/plant (SY/P) in percentage of the bulk and better parent (P).

\begin{tabular}{|c|c|c|c|c|c|c|c|c|c|c|c|c|}
\hline \multirow[b]{2}{*}{ Families } & \multicolumn{3}{|c|}{ Plant height } & \multicolumn{3}{|c|}{ Fruiting zone length } & \multicolumn{3}{|c|}{ Capsule length } & \multicolumn{3}{|c|}{ Branches No./plant } \\
\hline & Mean & $\begin{array}{c}\text { Better } \\
\text { P }\end{array}$ & Bulk & Mean & $\begin{array}{c}\text { Better } \\
\mathbf{P}\end{array}$ & Bulk & Mean & $\begin{array}{c}\text { Better } \\
\mathbf{P}\end{array}$ & Bulk & Mean & $\begin{array}{c}\text { Better } \\
\mathbf{P}\end{array}$ & Bulk \\
\hline 51 & 226.0 & 2.73 & 11.15 & 136.0 & -11.30 & -1.69 & 4.1 & 6.75 & 1.42 & 3.64 & -9.08 & 3.90 \\
\hline 52 & 184.0 & -16.36 & -9.51 & 122.7 & -20.00 & -11.33 & 4.4 & 15.53 & 9.75 & 4.30 & 7.58 & 22.95 \\
\hline 61 & 230.0 & 4.55 & 13.11 & 138.3 & -9.78 & 0.00 & 4.4 & 15.53 & 9.75 & 3.27 & -18.25 & -6.57 \\
\hline 109 & 222.0 & 0.91 & 9.18 & 133.0 & -13.26 & -3.86 & 4.6 & 22.11 & 16.00 & 3.94 & -1.58 & 12.48 \\
\hline 111 & 225.5 & 2.50 & 10.90 & 131.2 & -14.46 & -5.18 & 3.8 & 0.61 & -4.42 & 2.77 & -30.75 & -20.86 \\
\hline 115 & 243.5 & 10.68 & 19.75 & 141.7 & -7.61 & 2.41 & 4.6 & 22.11 & 16.00 & 3.97 & -0.75 & 13.43 \\
\hline 122 & 222.0 & 0.91 & 9.18 & 135.3 & -11.74 & -2.17 & 4.6 & 22.11 & 16.00 & 2.94 & -26.58 & -16.10 \\
\hline 127 & 233.0 & 5.91 & 14.59 & 138.7 & -9.57 & 0.24 & 5.1 & 33.07 & 26.42 & 4.64 & 15.92 & 32.48 \\
\hline 128 & 231.0 & 5.00 & 13.61 & 163.7 & 6.74 & 18.31 & 3.9 & 2.37 & -2.75 & 4.14 & 3.42 & 18.19 \\
\hline 166 & 207.7 & -5.61 & 2.13 & 127.2 & -17.07 & -8.07 & 4.6 & 22.11 & 16.00 & 3.10 & -22.42 & -11.33 \\
\hline Average & 222.5 & 1.12 & 9.41 & 136.8 & -10.80 & -1.13 & 4.4 & 16.23 & 10.42 & 3.67 & -8.25 & 4.86 \\
\hline $\mathbf{P}_{1}$ & 189.3 & & & 116.7 & & & 3.6 & & & 3.67 & & \\
\hline $\mathbf{P}_{2}$ & 220.0 & & & 153.3 & & & 4.0 & & & 4.00 & & \\
\hline Bulk & 203.3 & & & 138.3 & & & 4.0 & & & 4.00 & & \\
\hline RLSD $_{0.05}$ & 14.72 & & & 11.15 & & & 0.48 & & & 0.92 & & \\
\hline \multirow[b]{2}{*}{ Families } & \multicolumn{3}{|c|}{ Capsules No./plant } & \multicolumn{3}{|c|}{ Seed yield/plant (g) } & \multicolumn{3}{|c|}{ 1000-seed weight (g) } & \multicolumn{3}{|c|}{ Oil \% } \\
\hline & Mean & $\begin{array}{c}\text { Better } \\
\mathbf{P}\end{array}$ & Bulk & Mean & Better P & Bulk & Mean & $\begin{array}{c}\text { Better } \\
\text { P }\end{array}$ & Bulk & Mean & $\begin{array}{c}\text { Better } \\
\mathbf{P}\end{array}$ & Bulk \\
\hline 51 & 120.9 & 26.8 & 14.1 & 40.0 & 95.4 & 48.1 & 4.0 & 28.7 & 25.5 & 56.0 & -3.0 & 15.4 \\
\hline 52 & 136.1 & 42.7 & 28.4 & 36.8 & 79.8 & 36.3 & 3.5 & 11.1 & 8.3 & 58.3 & 1.1 & 20.2 \\
\hline 61 & 121.7 & 27.6 & 14.8 & 42.7 & 108.5 & 58.0 & 4.5 & 45.5 & 41.9 & 54.0 & -6.4 & 11.3 \\
\hline 109 & 134.0 & 40.6 & 26.5 & 39.9 & 95.0 & 47.8 & 4.5 & 43.2 & 39.6 & 48.3 & -16.4 & -0.5 \\
\hline 111 & 119.7 & 25.6 & 12.9 & 40.0 & 95.2 & 48.0 & 4.1 & 30.3 & 27.1 & 55.2 & -4.3 & 13.9 \\
\hline 115 & 150.0 & 57.3 & 41.5 & 45.7 & 123.1 & 69.1 & 4.9 & 56.0 & 52.1 & 57.0 & -1.2 & 17.5 \\
\hline 122 & 117.3 & 23.1 & 10.7 & 37.3 & 82.4 & 38.3 & 3.8 & 20.7 & 17.7 & 59.3 & 2.7 & 22.2 \\
\hline 127 & 172.7 & 81.1 & 62.9 & 46.5 & 127.2 & 72.2 & 4.7 & 51.2 & 47.4 & 42.2 & -26.9 & -13.1 \\
\hline 128 & 155.2 & 62.8 & 46.4 & 45.8 & 123.5 & 69.4 & 4.1 & 31.9 & 28.6 & 52.0 & -9.9 & 7.2 \\
\hline 166 & 126.0 & 32.1 & 18.8 & 40.3 & 97.1 & 49.4 & 4.6 & 48.0 & 44.3 & 57.6 & -0.2 & 18.7 \\
\hline Average & 135.4 & 42.0 & 27.7 & 41.5 & 102.7 & 53.7 & 4.3 & 36.7 & 33.3 & 54.0 & -6.4 & 11.3 \\
\hline $\mathbf{P}_{1}$ & 79.0 & & & 17.0 & & & 3.1 & & & 57.7 & & \\
\hline $\mathbf{P}_{2}$ & 95.3 & & & 20.5 & & & 2.9 & & & 55.0 & & \\
\hline Bulk & 106.0 & & & 27.0 & & & 3.2 & & & 48.5 & & \\
\hline RLSD $_{0.05}$ & 14.74 & & & 6.58 & & & 0.60 & & & 4.64 & & \\
\hline
\end{tabular}

and two families out of ten showed $\mathrm{P}$ 't significant increase than the bulk mean and the better parent, respectively.

\subsection{Independent culling levels procedure 3.3.1. Variances and means}

The analysis of variance for the selected families of independent culling levels for cycle 1 ( $\mathrm{F}_{4}$ generation) and cycle $2\left(\mathrm{~F}_{5}\right.$ generation) is shown in Table (9). The results indicated highly significant differences among genotypes.

Means, genotypic and phenotypic coefficients of variability and heritability in broad-sense (H.B.S) of cycles 1 and 2 of independent culling levels for studied traits are presented in Table (10).

The average seed yield/plant of the selected families (Table 10) increased from $36.01 \mathrm{~g}$ in $\mathrm{F}_{4}$ generation (cycle 1) to $42.20 \mathrm{~g}$ in $\mathrm{F}_{5}$ generation (cycle 2). The length of the fruit zone increased from $148.09 \mathrm{~cm}$ in $\mathrm{F}_{4}$ generation (cycle 1) to 165.02 in $F_{5}$ generations (cycle 2). While, increasing the length of the fruit zone and the number of capsules per plant from $(148.09 \mathrm{~cm}$ and 122.32) in $\mathrm{F}_{4}$ generation (cycle 1) to (165.02 and 140.16) in $\mathrm{F}_{5}$ generation (cycle 2), respectively. 
Table (9): Analysis of variance after the first and the second cycles for independent culling levels.

\begin{tabular}{|c|c|c|c|c|c|c|c|c|c|c|}
\hline \multirow{2}{*}{$\begin{array}{l}\text { Cycle } \\
\text { No. }\end{array}$} & \multirow[b]{2}{*}{ S.O.V } & \multirow[b]{2}{*}{ d.f } & \multicolumn{8}{|c|}{ Mean squares } \\
\hline & & & $\begin{array}{c}\text { Plant } \\
\text { height }\end{array}$ & $\begin{array}{l}\text { Fruiting } \\
\text { zone } \\
\text { length }\end{array}$ & $\begin{array}{l}\text { Capsule } \\
\text { length }\end{array}$ & $\begin{array}{c}\text { Branc } \\
\text { hes } \\
\text { No. / } \\
\text { plant }\end{array}$ & $\begin{array}{c}\text { Capsules } \\
\text { No./ } \\
\text { plant }\end{array}$ & $\begin{array}{c}\text { Seed } \\
\text { yield/plant }\end{array}$ & $\begin{array}{c}1000- \\
\text { seed } \\
\text { weight }\end{array}$ & $\begin{array}{l}\text { Oil } \\
\%\end{array}$ \\
\hline \multirow{3}{*}{$\begin{array}{l}\mathbf{C}_{1} \\
\left(\mathbf{F}_{4}\right)\end{array}$} & Replication & 2 & 242.14 & 884.44 & 4.36 & 4.06 & 3087.14 & 485.64 & 1.53 & 6.66 \\
\hline & Genotypes & 29 & 1671.30 ** & $1315.58 * *$ & $0.61^{* *}$ & $1.46^{* *}$ & $3521.48^{* *}$ & $7721.85 * *$ & $0.89 * *$ & $80.39 * *$ \\
\hline & Error & 58 & 151.97 & 146.87 & 0.20 & 0.20 & 208.25 & 1759.07 & 0.11 & 8.26 \\
\hline \multirow{3}{*}{$\begin{array}{l}\mathrm{C}_{2} \\
\left(\mathrm{~F}_{5}\right)\end{array}$} & Replication & 2 & 142.97 & 410.91 & 0.31 & 0.10 & 310.89 & 192.99 & 0.35 & 0.19 \\
\hline & Genotypes & 9 & $627.50^{* *}$ & $1099.68 * *$ & $0.67 * *$ & $1.64 * *$ & $2329.63 * *$ & $581.05^{* *}$ & $0.53 * *$ & $90.74 * *$ \\
\hline & Error & 18 & 100.41 & 140.91 & 0.07 & 0.13 & 113.38 & 133.86 & 0.05 & 6.15 \\
\hline
\end{tabular}

After two selection cycles of independent culling levels procedure, the (GCV) of seed yield/plant, fruiting zone length and capsules No./plant were decreased to $10.40,10.83$ and $18.68 \%$, respectively, compared to $11.47,7.10$ and $12.97 \%$ in single trait selection for seed yield/plant, respectively. El-Shimy (1995) found that the realized seed yield/plot was 46.34, 26.83 and $21.95 \%$ in population I and 22.95, 36.07 and 40.16 in population II using selection index, independent culling levels and pedigree selection, respectively after two cycles of selection.

In general, it could be concluded that the genetic variability retained after independent culling levels was larger than that obtained from single trait selection. These results were expected because single trait selection was exerted and directed to one trait only (selection criterion), however, independent culling levels was directed to all traits incorporated. El-Shimy (2005) found that the genetic variability retained after (ICL) was larger than that after single trait selection.

\subsubsection{Heritability and realized heritability estimates}

The results in Table (10) showed that estimates of heritability in the broad sense after two cycles of independent culling

Table (10): Means, range, phenotypic (PCV \%), genotypic (GCV \%) coefficients of variability, heritability in broad-sense (H.B.S) and realized heritability in the two cycles of independent culling levels.

\begin{tabular}{|c|c|c|c|c|c|c|c|c|c|c|}
\hline $\begin{array}{c}\text { Cycle } \\
\text { No. }\end{array}$ & \multicolumn{2}{|c|}{ Item } & $\begin{array}{c}\text { Plant } \\
\text { height } \\
\text { (cm) }\end{array}$ & $\begin{array}{l}\text { Fruitin } \\
\text { g zone } \\
\text { length } \\
\text { (cm) }\end{array}$ & $\begin{array}{c}\text { Capsule } \\
\text { length } \\
\text { (cm) }\end{array}$ & $\begin{array}{c}\text { Branches } \\
\text { No. / } \\
\text { plant }\end{array}$ & $\begin{array}{c}\text { Capsules } \\
\text { No. / } \\
\text { plant }\end{array}$ & $\begin{array}{c}\text { Seed } \\
\text { yield/ } \\
\text { plant } \\
(\mathrm{g})\end{array}$ & $\begin{array}{c}1000- \\
\text { seed } \\
\text { weight } \\
\text { (g) }\end{array}$ & $\begin{array}{l}\text { Oil } \\
\%\end{array}$ \\
\hline \multirow{11}{*}{$C_{1}\left(F_{4}\right)$} & \multirow{2}{*}{ Range } & Min. & 123.33 & 68.67 & 2.33 & 1.00 & 50.40 & 10.07 & 2.73 & 32.67 \\
\hline & & Max. & 253.33 & 157.67 & 5.40 & 7.67 & 191.67 & 46.10 & 6.67 & 66.58 \\
\hline & \multicolumn{2}{|c|}{$\begin{array}{l}F_{4} \text { selected } \\
\text { families }\end{array}$} & 206.52 & 148.09 & 3.78 & 3.84 & 122.32 & 36.01 & 4.10 & 49.32 \\
\hline & \multicolumn{2}{|l|}{$\mathbf{P}_{1}$} & 189.33 & 116.67 & 3.63 & 3.67 & 79.00 & 19.33 & 3.12 & 57.69 \\
\hline & \multicolumn{2}{|l|}{$\mathbf{P}_{2}$} & 245.00 & 153.33 & 4.00 & 4.00 & 95.33 & 22.40 & 2.90 & 55.00 \\
\hline & \multicolumn{2}{|l|}{ Bulk } & 179.70 & 121.12 & 3.49 & 3.48 & 86.14 & 23.38 & 3.83 & 48.71 \\
\hline & \multicolumn{2}{|l|}{ CV\% } & 5.97 & 8.18 & 11.84 & 11.75 & 11.80 & 15.29 & 8.10 & 5.83 \\
\hline & \multicolumn{2}{|c|}{ PCV \% } & 10.90 & 13.33 & 9.80 & 16.84 & 27.17 & 24.63 & 12.48 & 9.94 \\
\hline & \multicolumn{2}{|c|}{ GCV \% } & 11.43 & 14.14 & 11.95 & 18.15 & 28.01 & 26.16 & 13.33 & 10.50 \\
\hline & \multicolumn{2}{|c|}{ H.B.S \% } & 90.91 & 88.84 & 67.27 & 86.03 & 94.09 & 88.61 & 87.69 & 89.73 \\
\hline & \multicolumn{2}{|c|}{$\begin{array}{l}\text { Realized } \\
\text { heritability }\end{array}$} & 0.33 & 0.66 & 0.30 & 0.87 & 0.82 & 0.94 & 0.73 & 0.70 \\
\hline \multirow{11}{*}{$\begin{array}{c}\mathbf{C}_{2} \\
\left(\mathbf{F}_{5}\right)\end{array}$} & \multirow[b]{2}{*}{ Range } & Min. & 202.17 & 138.33 & 3.42 & 1.67 & 110.37 & 38.33 & 3.54 & 42.15 \\
\hline & & Max. & 247.33 & 204.33 & 5.06 & 4.64 & 187.47 & 52.33 & 4.72 & 63.64 \\
\hline & \multicolumn{2}{|c|}{$\begin{array}{l}F_{5} \text { selected } \\
\text { families }\end{array}$} & 231.70 & 165.02 & 4.04 & 3.47 & 145.54 & 42.20 & 4.09 & 53.17 \\
\hline & \multicolumn{2}{|l|}{$\mathbf{P}_{1}$} & 189.33 & 116.67 & 3.63 & 3.67 & 79.00 & 17.00 & 3.12 & 57.69 \\
\hline & \multicolumn{2}{|l|}{$\mathbf{P}_{2}$} & 220.00 & 153.33 & 4.00 & 3.67 & 95.33 & 20.47 & 2.90 & 55.00 \\
\hline & \multicolumn{2}{|l|}{ Bulk } & 203.33 & 138.33 & 4.00 & 4.00 & 106.00 & 20.00 & 3.57 & 51.90 \\
\hline & \multicolumn{2}{|l|}{ CV\% } & 4.32 & 7.19 & 6.73 & 10.23 & 7.32 & 6.50 & 5.30 & 4.66 \\
\hline & \multicolumn{2}{|c|}{ PCV \% } & 5.72 & 10.83 & 11.05 & 20.51 & 18.68 & 9.96 & 9.80 & 9.99 \\
\hline & \multicolumn{2}{|c|}{ GCV \% } & 6.24 & 11.60 & 11.72 & 21.35 & 19.15 & 10.32 & 10.27 & 10.34 \\
\hline & \multicolumn{2}{|c|}{ H.B.S \% } & 84.00 & 87.19 & 89.00 & 92.34 & 95.13 & 93.03 & 91.12 & 93.23 \\
\hline & \multicolumn{2}{|c|}{$\begin{array}{l}\text { Realized } \\
\text { heritability }\end{array}$} & 0.37 & 0.15 & 0.91 & 0.68 & 0.58 & 0.16 & -0.76 & 0.43 \\
\hline
\end{tabular}


levels procedure were high for all traits. The realized heritability estimated from the realized gain in both cycles of independent culling levels selection in the studied population decreased from $\mathrm{C}_{1}$ to $\mathrm{C}_{2}$ and all correlated traits, revealing the less genetic variation in $\mathrm{C}_{2}$ comparing to $\mathrm{C}_{1}$. El-Shimy (1995) and Ismail et al. (2013) reported similar results.

\subsubsection{The expected genetic gain from selection}

The expected genetic gain from selection in relation to bulk mean and better parents (Table 7), revealed high percentage in most studied traits. Genetic advance as percentage of bulk means after carrying out two cycles of independent culling levels was high for capsules No./plant (29.01 \%) followed by seed yield/plant $(23.81 \%)$ and fruiting zone length (14.0\%). Similarly, genetic advance as percent of better parent was high for capsules No./plant (32.26 \%) followed by seed yield/plant $(23.26 \%)$ after carrying out two cycles of independent culling levels selection.

3.3.4. Observed direct and correlated responses after applying two cycles of independent culling levels selection.

Table (11) shows the means (observed direct) of the best 10 families selected according to the selection independent culling levels and correlated responses after carrying out two cycles in $\mathrm{F}_{5}$ generation. The correlated responses were estimated as percentage from bulk's mean and better parent. Results show that the independent culling levels selection succeeded to isolate superior genotypes in seed yield/plant with one or more effective attributed traits.

After two cycles of selection, all the selected families were highly significantly improved than the bulk sample and the best parent for length of

Table (11): Observed direct and correlated responses after two cycles of pedigree selection for independent culling levels in percentage of the bulk and better parent $(P)$.

\begin{tabular}{|c|c|c|c|c|c|c|c|c|c|c|c|c|}
\hline \multirow[b]{2}{*}{ Families } & \multicolumn{3}{|c|}{ Plant height } & \multicolumn{3}{|c|}{ Length of fruiting zone } & \multicolumn{3}{|c|}{ Capsule length } & \multicolumn{3}{|c|}{ Branches No./plant } \\
\hline & Mean & $\begin{array}{l}\text { Better } \\
\mathbf{P}\end{array}$ & Bulk & Mean & $\begin{array}{l}\text { Better } \\
\text { P }\end{array}$ & Bulk & Mean & $\begin{array}{l}\text { Better } \\
\text { P }\end{array}$ & Bulk & Mean & $\begin{array}{l}\text { Better } \\
\mathbf{P}\end{array}$ & Bulk \\
\hline 34 & 202.2 & -8.11 & -0.57 & 156.7 & 2.17 & 13.25 & 3.4 & -10.09 & -14.58 & 3.5 & -12.50 & 0.00 \\
\hline 35 & 239.0 & 8.64 & 17.54 & 172.7 & 12.61 & 24.82 & 4.0 & 5.26 & 0.00 & 1.7 & -58.33 & -52.38 \\
\hline 39 & 241.5 & 9.77 & 18.77 & 161.5 & 5.33 & 16.75 & 4.3 & 11.84 & 6.25 & 3.3 & -16.67 & -4.76 \\
\hline 49 & 234.0 & 6.36 & 15.08 & 168.0 & 9.57 & 21.45 & 4.0 & 5.26 & 0.00 & 3.7 & -8.33 & 4.76 \\
\hline 52 & 220.0 & 0.00 & 8.20 & 162.3 & 5.87 & 17.35 & 3.9 & 3.07 & -2.08 & 3.4 & -14.17 & -1.90 \\
\hline 56 & 222.0 & 0.91 & 9.18 & 138.3 & -9.78 & 0.00 & 4.4 & 15.53 & 9.75 & 3.3 & -18.25 & -6.57 \\
\hline 87 & 247.3 & 12.42 & 21.64 & 204.3 & 33.26 & 47.71 & 4.0 & 5.26 & 0.00 & 3.8 & -4.17 & 9.52 \\
\hline 122 & 223.0 & 1.36 & 9.67 & 138.7 & -9.57 & 0.24 & 5.1 & 33.07 & 26.42 & 4.6 & 15.92 & 32.48 \\
\hline 130 & 245.0 & 11.36 & 20.49 & 169.7 & 10.65 & 22.65 & 3.9 & 3.07 & -2.08 & 3.7 & -6.67 & 6.67 \\
\hline 142 & 243.0 & 10.45 & 19.51 & 178.0 & 16.09 & 28.67 & 3.4 & -10.09 & -14.58 & 3.6 & -10.00 & 2.86 \\
\hline Average & 231.7 & 5.32 & 13.95 & 165.0 & 7.62 & 19.29 & 4.0 & 6.22 & 0.91 & 3.5 & -13.32 & -0.93 \\
\hline$P_{1}$ & 189.3 & & & 116.7 & & & 3.6 & & & 3.7 & & \\
\hline $\mathbf{P}_{2}$ & 220.0 & & & 153.3 & & & 4.0 & & & 4.0 & & \\
\hline Bulk & 203.3 & & & 138.3 & & & 4.0 & & & 4.0 & & \\
\hline LSD $_{0.05}$ & 16.61 & & & 19.68 & & & 0.43 & & & 0.56 & & \\
\hline \multirow{2}{*}{ Families } & \multicolumn{3}{|c|}{ No. of capsules/plant } & \multicolumn{3}{|c|}{ Seed yield/plant (g) } & \multicolumn{3}{|c|}{ 1000-seed weight (g) } & \multicolumn{3}{|c|}{ Oil \% } \\
\hline & Mean & Better P & Bulk & Mean & Better P & Bulk & Mean & Better P & Bulk & Mean & Better P & Bulk \\
\hline 34 & 110.4 & 15.8 & 4.1 & 40.5 & 98.0 & 102.7 & 4.6 & 46.6 & 28.2 & 53.4 & -7.4 & 2.9 \\
\hline 35 & 187.5 & 96.6 & 76.9 & 38.7 & 88.9 & 93.3 & 3.7 & 18.8 & 3.9 & 63.6 & 10.3 & 22.6 \\
\hline 39 & 116.8 & 22.5 & 10.2 & 38.3 & 87.3 & 91.7 & 4.1 & 30.0 & 13.7 & 53.7 & -6.9 & 3.5 \\
\hline 49 & 135.1 & 41.7 & 27.4 & 41.9 & 104.8 & 109.5 & 3.5 & 13.5 & -0.7 & 51.7 & -10.4 & -0.4 \\
\hline 52 & 160.9 & 68.7 & 51.8 & 52.3 & 155.7 & 161.7 & 4.0 & 28.4 & 12.3 & 49.1 & -15.0 & -5.5 \\
\hline 56 & 121.7 & 27.6 & 14.8 & 42.7 & 108.5 & 113.3 & 4.5 & 45.5 & 27.3 & 54.0 & -6.4 & 4.0 \\
\hline 87 & 156.4 & 64.1 & 47.5 & 42.5 & 107.7 & 112.6 & 4.3 & 36.4 & 19.3 & 51.7 & -10.3 & -0.3 \\
\hline 122 & 172.7 & 81.1 & 62.9 & 46.5 & 127.2 & 132.5 & 4.7 & 51.2 & 32.2 & 42.2 & -26.9 & -18.8 \\
\hline 130 & 173.5 & 81.9 & 63.6 & 38.3 & 87.3 & 91.7 & 3.9 & 25.2 & 9.5 & 56.9 & -1.4 & 9.6 \\
\hline 142 & 120.7 & 26.6 & 13.8 & 40.2 & 96.4 & 101.0 & 3.6 & 15.4 & 0.9 & 55.5 & -3.8 & 6.9 \\
\hline Average & 145.5 & 52.7 & 37.3 & 42.2 & 106.2 & 111.0 & 4.1 & 31.1 & 14.7 & 53.2 & -7.8 & 2.5 \\
\hline $\mathbf{P}_{1}$ & 79.0 & & & 17.0 & & & 3.1 & & & 57.7 & & \\
\hline $\mathbf{P}_{2}$ & 95.3 & & & 20.5 & & & 2.9 & & & 55.0 & & \\
\hline Bulk & 106.0 & & & 20.0 & & & 3.6 & & & 51.9 & & \\
\hline LSD $_{0.05}$ & 16.2 & & & 4.3 & & & 0.3 & & & 3.9 & & \\
\hline
\end{tabular}


the fruiting zone, number of capsules No./plant and seed yield/plant. It is important to remark that the selected family No.35 exceeds significantly its best parent and bulk for seed yield/plant and branches No./plant \%. It has been observed that there are common families between the pedigree method of selection and the method of independent culling levels. Of these families, are No.56 and No. 122, which were considered good families selected to achieve high potentiality of seed yield/plant trait.

\section{REFERENCES}

Al-Jibouri H.A., Hiller P.A. and Robinson H.F. (1958). Genotypic and environmental variances and covariances in upland cotton cross of interspecific origin. Agron. J., 50: 633636.

Abo-Elwafa A. and Ahmed T.A. (2005). Efficiency of pedigree line selection and contributions of different traits in seed yield and oil through two cycles of selection in sesame (Sesamum indicum L.). Assiut J. Agri. Sci., 36(2):1-24.

A.O.A.C. (1980). Official Methods of Analysis Association of Official Agric. Chemists $13^{\text {th }}$ ed., A.O.A.C., Washington, D.C., USA.

Akbar F., Rabbani M.A., Shinwari Z.K. and Khan S.J. (2011). Genetic divergence in sesame (Sesamum indicum L.) landraces based on qualitative and quantitative traits. Pak. J. Bot., 43: 2737-2744.

Ashri A. (2007). Sesame (Sesamum indicum, L.). In: Singh RJ (ed.) Genetics Resources, Chromosome Engineering, and Crop Improvement, Vol.4, Oilseed Crops, CRC Press, Boca Raton, FL., USA.

Burton G. W. (1952). Quantitative inheritance in grasses. $6^{\text {th }}$ Int'l. Grassland Congr., 1: 277-283.

Chowdhury S., Datta A.K., Saha A., Sengupta S., Paul Maity R..S. and Das A. (2010). Traits influencing yield in sesame (Sesamum indicum, L.) and multi locational trials of yield parameters in some desirable plant types. Indian J. Sci. Technol., 3: 163166.

El-Shakhess Samar A.M., Madkour M.A. and El-Bas M.G.M. (2002). Yield Improvement in Sesame (Sesamum indicum, L.) via selection index. Egypt J. Plant Breed., 6 (2): 121-132.

El-Shimy A.A. (1995). The efficiency of some selection procedures in sesame (Sesamum indicum L.). Ph.D. Thesis, Fac. Agric. Assiut Univ., pp. 1-164.

El-Shimy A.A. (2005). Contributions of different traits in seed yield through two cycles of pedigree line selection in sesame (Sesamum indicum L.). Assiut J. Agric. Sci., 36 (4): 125-141.

El-Shimy A.A., Sedeck F.S., Ismail A.A. and Bahy R. (2005). Pedigree selection and independent culling levels methods in sesame (Sesamum indicum L.). The $11^{\text {th }}$ Conference of Agronomy, Agron. Dept., Fac. Agric., Assiut Univ., Nov. 15-16, Egypt. pp: 401-419.

Falconer D.S. (1989). Introduction to Quantitative Genetics. Longman, London (UK), New York (USA).

Gidey Y.T., Kebede S.A. and Gashawbeza G.T. (2013). Assessment of genetic variability, genetic advance, correlation and path analysis for morphological traits in sesame genotypes. International J.Plant Breed. Genet., 7: 21-34.

Ismail A.A., Abo-Elwafa A., Sedeck F.S. and Abd-Elsaber A. (2013). Pedigree selection for yield and its components in sesame (Sesamum indicum L.). 1Response to selection for yield, correlation and path coefficients analyses. Assiut J. Agric. Sci., 44(3):114.

Ismaila A. and Usman A. (2012). Genetic variability for yield and yield components in sesame (Sesamum indicum, L.). Int'l J.Sci. and Res., 3:358-361.

Kumar S., Gupta R.R., Chandra R. and Gupta G.R. (2012). Selection parameters for high yield and oil content in sesame (Sesamum indicum, L.). Curr. Ad. Agric. Sci. (Indian), 4: 2, 156-158.

Mahdy E.E., Ismail A. A., El-Shimy A.A., Sayed M.A. and Salah A. (2015). pedigree selection to improve seed yield in sesame. Egypt. J. Plant Breed., 19(2): $337-353$.

Menzir A. (2012). Phenotypic variability divergence analysis and heritability of characters in sesame (Sesamum 
indicum L.) genotypes. Nat. and Sci., 10 (10): 117-126.

Parameshwarappa S.G., Palakshppa M.G, Salimath P.M. and Parameshwarappa K.G. (2009). Studies on genetic variability and character association in germplasm collection of sesame (Sesamum indicum L.). Karnataka J. Agric. Sci., 22(2): 252-254.

Sivaprasad Y.V.N. and Yadavalli V. (2012). Correlation, path analysis and genetic variability in F2 and F3 generations of cross Padma $\times$ JLSV 4 in sesames
(Sesamum indicum L.). Int'l. J. Agric. Sci., 2 (12): 311- 314.

Steel R.G.D., Torrie J.H. and Dickey D.A. (1997). Principles and Procedures of Statistics. A Biometrical Approach. $3^{\text {rd }}$ ed., Mc Grow-Hill Inc., New York, USA.

Sumathi P. and Muralidharan V. (2010). Analysis of genetic variability, association and path analysis in the hybrids of sesame (Sesamum indicum L.). Tropical Agric. Res. \& Exten., 13(3): 63-67.

مقارنة بين الإتتخاب بطريقة تسجيل النسب وطريقة المستويات المستبعدة المستقلة

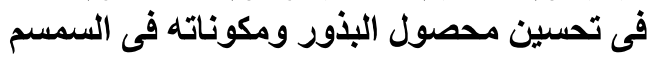

أحمد عبد الصابر - نبيل إسحق جرجس ميخائيل*

قسم بحوث المحاصيل الزيتية ـ معهد بحوث الدحاصيل الحقلية و*المعدل المركزي لبحوث التصميم و التحليل الإحصائي-

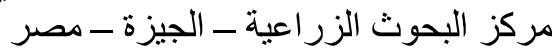

أجرى هذا البحث بمحطة البحوث الزر اعية بالمطاعنة - محافظة الأقصر ـ مصر خلال ثلاثث مو اسم صيفية من 2016

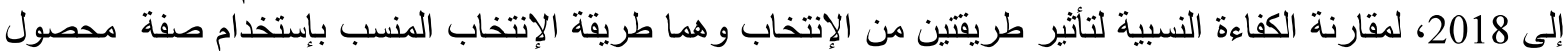

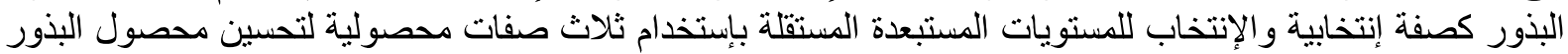

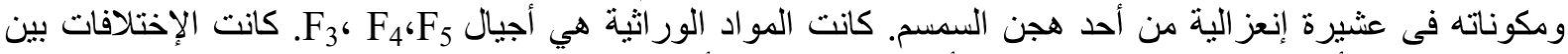

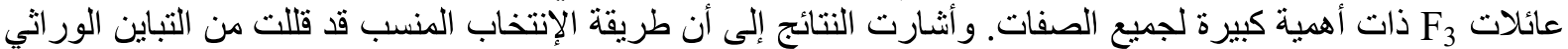

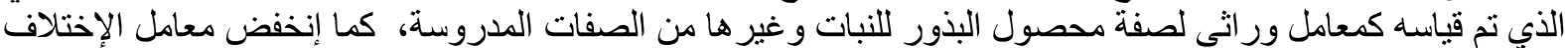

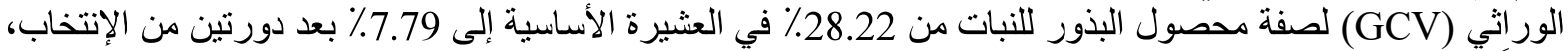

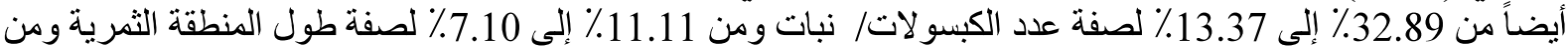

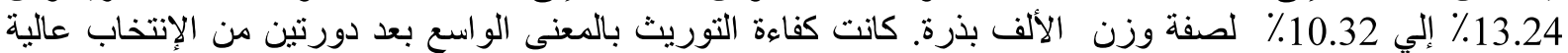

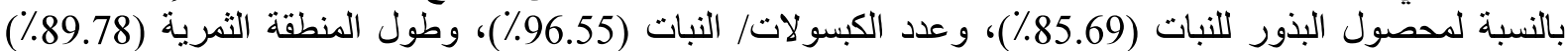

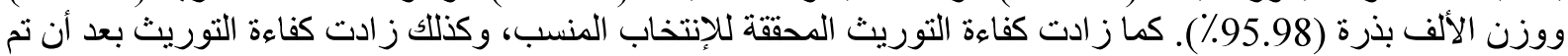

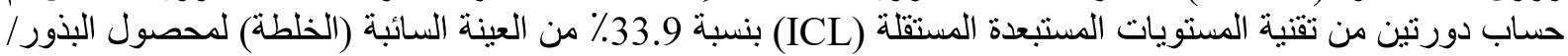
نبات. وكانت كفاءة التوريث بالمعنى الو اسع بعد دورتين من (ICL) عالية لجميع الصفات الصنات.

المجلة العلمية لكلية الزراعة - جامعة القاهرة- المجلا (71) العدد الثانى ابريل (2020): 61-71. 